\section{English language teaching in a public school in Brazil: an experience of a student teacher in a state school}

O ensino de língua inglesa em uma escola pública no Brasil: uma experiência de uma estagiária em uma escola estadual

Laryssa Paulino de Queiroz SOUSA (UFG) laryssa.paulino1@gmail.com Alexandre de Araújo BADIM (UFG) alexandre.badim@gmail.com

Eliane Carolina de OLIVEIRA (UFG) ecaol2@gmail.com

Recebido em: 14 de jun. de 2018. Aceito em: 10 de ago. de 2018.
SOUSA, Laryssa Paulino de Queiroz; BADIM, Alexandre de Araújo; OLIVEIRA, Eliane Carolina de. English language teaching in a public school in Brazil: an experience of a student teacher in a state school Entrepalavras, Fortaleza, v. 8, n. 3, p. 320-335, out-dez/2018

Abstract: This study revolves around the English practicum experience of a Brazilian student teacher in a state school of Goiás, in Brazil. The objectives of this paper are to investigate the aspects that stand out in the experience in question and the impact of it on the undergraduate's professional life. In dialogue with studies carried out by Weiss (1999), Bernardo (2007), Andrade et al (2013), Marzari and Genhres (2015), among others, the topics addressed are: general problems concerning the teaching and learning process; specific issues that affect the work development of the collaborating teachers; the characterization of the English classes observed; and the impact of the practicum experience on the student teacher. This research is a qualitative case study, with its focus on documental analysis. As results, several aspects regarding daily difficulties and challenges faced by teachers are highlighted, from the undergraduate's perspective, as well as consequences of their influence on the teaching and learning process of English in the state school where the study was undertaken. Besides that, it is possible to perceive that the English practicum can affect student teachers greatly, leading them to changes in the professional choices made by them.

Keywords: English language teaching. Practicum. State school. 
Resumo: Este estudo foca na experiência de estágio de língua inglesa de uma aluna brasileira em uma escola estadual de Goiás, no Brasil. Os objetivos deste artigo são investigar os aspectos destacados na experiência da aluna e o impacto dela sobre a vida profissional da graduanda. Em diálogo com estudos realizados por Weiss (1999), Bernardo (2007), Andrade et al. (2013), Marzari e Genhres (2015), entre outros, os tópicos abordados são: problemas gerais concernentes ao processo de ensino e aprendizagem; questões específicas que afetam o desenvolvimento do trabalho das professoras-colaboradoras; a caracterização das aulas de inglês observadas; e o impacto da experiência de estágio sobre a estagiária. Esta pesquisa é um estudo de caso qualitativo, cujo enfoque é a análise documental. Como resultados, são destacados diversos aspectos no que concerne às dificuldades e aos desafios diários enfrentados por docentes, a partir da perspectiva da graduanda, bem como as consequências de suas influências sobre o processo de ensino e a aprendizagem de inglês na escola estadual onde o estudo foi desenvolvido. Além disso, é possível perceber que o estágio de língua inglesa pode afetar fortemente os estagiários, ao levá-los a mudanças nas escolhas profissionais feitas por eles.

Palavras-chave: Ensino de língua inglesa. Estágio. Escola estadual.

\section{Introduction}

This study focuses on the English practicum experience of a student teacher from Faculdade de Letras of the Federal University of Goiás, in Brazil, during 2013 and 2014.

In brief, undergraduates have English teaching classes focused on practicum experiences for four semesters, namely English Practicum 1, 2, 3 and 4. In each semester, a university professor teaches theoretical and practical issues related to the teaching and learning process of English and guides, supervises and aids student teachers with their practicum experiences in field schools.

In general, English undergraduates are supposed to: a) observe and investigate the school context, especially English classes; b) read, reflect on and discuss academic and non-academic texts that include aspects related to education and teaching; and c) implement teaching sessions and develop their final papers based on them.

This investigation is characterized as a qualitative case study, with its focus on documental analysis. As the general objective of this research, we aim to discuss some aspects related to English language classes in a state school. Thus, through this study, we sought to answer the following questions:

a) Which aspects stand out in the practicum experience of an English student teacher?

b) How did the practicum experience affect the undergraduate? This paper is divided into four parts. In the introduction, we 
V. 8 (3)

320-335

out-dez

2018

present the main information about the investigation and its guiding questions. In the methodology, we explain the kind of study we carried out as well as how the data was collected and generated. Then, in the data analysis and discussion, we present the data and reflect on them. In the final remarks, we answer the questions that guided this research.

\section{Methodology}

This investigation is a qualitative case study because the focus is on the data generated from the practicum experience and perceptions of one single student teacher at one field school, over two years. For Godoy (2006), this kind of study concentrates on a specific case. As Merriam (1988) points out, the researcher aims to understand the social processes that happen in a specific context. The meanings that surface through the interactions that happen are the focus of investigation (DENZIN; LINCOLN, 2003; GODOY, 2006).

This paper is based on a two-year documental analysis carried out by the undergraduate during her English language practicum experience. The school where she developed her practicum is located in Goiânia, capital of Goiás, a state of Brazil. The data were generated in 2013 and 2014. In each year, one collaborating teacher accompanied the student teacher; that said, for the purpose of facilitating the reading, the educator who participated in 2013 is addressed as collaborating teacher A and the one who participated in 2014 as collaborating teacher B.

During her practicum, the undergraduate generated:

a) fifteen records (which contain the student teacher's perceptions, answers provided by the coordinator, collaborating teachers and students from the field school);

b) fifteen essays written by her (based on the records and sharing sessions with her classmates, who were also student teachers);

c) four portfolios (organized by her as final assignments for each semester - the records and essays mentioned are assembled in them).

In the next section, we focus on the data analysis along with a theoretical discussion.

\section{Theoretical discussion and data analysis}

There are four main topics in this section: I. General problems; II. The collaborating teachers; III. The English classes; IV. Impact of the practicum experience on the student teacher. 
General problems

In this subsection, we concentrate on general issues that were of great concern to the student teacher during her practicum. To illustrate them, we present two excerpts:

\section{Excerpt 01}

Question: What did you think of the lessons you attended?

In relation to the classes I attended, I believe it would be impossible to give good classes in such overcrowded classrooms (in average 50 students in each), in which half of the groups were sleeping, while the [collaborating] teacher [A] was trying to do the activities with them, and the other half was talking loudly about topics unrelated to the subject of the class. Besides that, the educator had asked them to do an activity as homework, but from 50 students in each class, only around 04 of each group had done it. (Practicum 1 , Record 1, 06 May 2013)

\section{Excerpt 02}

Regarding the difficulties she [collaborating teacher B] has got to face daily at school, the educator stated it is too difficult to follow the annual plan required by the State Department of Education. Such plan is rarely related to the contents of the textbooks that are sent to the school. Furthermore, she declared that the contents proposed do not always include students' interests. At last, the teacher remarked on some more general problems, such as overcrowded classrooms, reduced time for foreign language classes (50 minutes/week), indiscipline, students' lack of interest, lack of resources and materials to create dynamic classes (for example, if students need copies of some activity asked by the teacher, they need to pay for them), etc. The latter is an aspect present even in the PCN ${ }^{1}$ (BRASIL, 2000, p. 25) - "a shortage of teaching materials", which is still quite common in many school contexts. (Practicum 4, Essay 1, 20 October 2014)

${ }^{1}$ PCNs are National Curricular Parameters (Parâmetros Curriculares Nacionais) laid down by the Brazilian government and used as pedagogical references and guidelines for teachers. 
V. 8 (3)

$320-335$

out-dez

2018

Regarding the classes she observed, only negative aspects are mentioned by the undergraduate. From that, it is possible to notice that she readily perceives the constraints and limitations of that context, but not its possibilities. Discussing such issue is also vital in teacher education courses, so that student teachers can learn to seek autonomy and develop their agency in order to make changes they consider necessary.

In excerpts 01 and 02 , the undergraduate mentions overcrowded classrooms, in which there were students sleeping or talking loudly while the collaborating teacher was trying to teach her lesson. This shows their indiscipline as well as their lack of interest concerning the lessons, for most learners did not even do their homework.

For many authors, among them Richards and Pennington (1998), Weiss (1999), Bernardo (2007), Marzari and Gehres (2015), Pontes and Davel (2016), and Lima and Silva (2018), teachers' dissatisfaction with class size is a general problem in the context of English language teaching in public schools. Large classes might hinder the teacher's control over what happens in classroom, as it is possible to notice in excerpt 01. As Bernardo (2007) and Andrade et al (2013) state, overcrowded classrooms also reduce the amount of time between teacher and students, as they have less time to give individual attention to learners.

Concerning their lack of interest, Weiss (1999) and Barcelos (2006) stress that students have poor motivation to learn, due to the teaching and learning conditions provided for them to study. As Andrade et al (2013) affirm, this also contributes to learners' bad performance. In Barcelos' words (2006, p. 155, 157),

[...] the learning experience in public schools is characterized as bad and demotivating, [...] [which] suggests a vision of public schools as a site where students' expectancies towards the teaching of English are not fulfilled. ${ }^{2}$

Hence, the same author also points out that the current reality of education in Brazil incites learners not to believe that the public school is a place where they can learn English. Perhaps because of such beliefs most students from excerpt 01 did not seem to make any effort to participate in the lesson.

\footnotetext{
${ }^{2}$ Original quote: "[...] a experiência de aprendizagem em escola pública é caracterizada como ruim e desmotivante, [...] [o que] sugere uma visão de escola pública como um local onde as expectativas dos alunos a respeito do ensino de inglês não são preenchidas".
} 
Another issue is the limited amount of time for English classes - aspect present in Andrade's et al (2013) study as well. As these authors highlight, the very short, fragmented and insufficient time for classes also causes limitations on the teaching of English. Thus, as they have an extremely short amount of time to work with learners, teachers cannot achieve the objectives proposed. The authors still claim that, because of the amount of time available to study the language, it would be an illusion to think that students would leave the school fluent in English. Bernardo (2007) even claims that, after studying English for four years (in elementary school) and/or three years (in high school), students finish their studies as if they had never studied the language.

Besides those problems, in excerpt 02, the collaborating teacher B stresses the discrepancies between the annual plan and the contents of the textbooks, which create another problem she has to deal with, as the documents and materials do not fit in with each other. This shows that the teaching materials are not adequate for teachers to develop their work (MARZARI; GEHRES, 2015). Besides that, lack of materials and resources is another problem, as for instance: "According to the [collaborating] teacher [B], not all students have the school textbook; for example, students from a whole group of the $9^{\text {th }}$ year do not have books. Even if she wanted to use the book, she could not because there is a whole group without it." (Practicum 3, Essay 2, 09 June 2014). According to Andrade et al (2013), unfortunately this is still a common problem in many state schools.

All the aspects mentioned contribute to teachers' demotivation to work in public schools. For Coelho (2005, p. 13), "English language teachers feel discouraged and limited by the conditions of the classrooms they encounter." 3 As Richards and Pennington (1998) claim, consequently many teachers choose not to do things differently than they are used to due to lack of motivation to do so and also because that would imply more effort from their part, in order to try new things. Consequently, they prefer a safe strategy of sticking close to what is already prescribed (RICHARDS; PENNINGTON, 1998).

It is important to question why problems such as the ones mentioned happen and what it is possible to do in order to try to mitigate them.

3 Original quote: "Os professores de LE se sentem desanimados e se vêem limitados diante das condições da sala de aula que encontram". 
V. 8 (3)

320-335

out-dez

2018

The collaborating teachers

In the following excerpts, we underline some aspects that characterize one of the collaborating teacher's work reality.

\section{Excerpt 03}

What is the workload of the collaborating teacher?

According to the interviewee [collaborating teacher A], the workload is the excessively heavy. She states that she gives 42 lessons per week, resulting in more than 40 hours per week, teaching both Portuguese and English. (Practicum 2, Record 1, 09 September 2013)

\section{Excerpt 04}

How do you think the working conditions (the school in which you collect your data) influence the professional that the collaborating teacher feels she is nowadays? (self)

I believe that, within their possibilities, the school staff tries to help the collaborating teacher $[\mathrm{A}]$. However, because of the current system she ended up moving away from what I understand as teaching English, always resorting to grammar and textbooks not only as support, but also as basis for her classes ${ }^{4}$. Monotonous lessons make students lose interest in learning. On the other hand, by considering the routine of the collaborating teacher, I understand the reasons that led her to do things the way she does. She demonstrates she likes what she does, but for a teacher, mother, housewife, who works more than 40 hours a week, there is not much time left to prepare lessons. (Practicum 2, Record 1, o9 September 2013, emphasis in original)

In excerpts 03 and 04 , the student teacher emphasizes the huge workload that the collaborating teacher A has to cope with. Teachers that participated in Crookes and Arakaki's research (1999 in BORG, 2003, p. 94) also complain about "heavy workloads (approximately 50 hours a week)." From that, we understand that such difficult working conditions have an enormous effect on what teachers do and do not do. Hence, the undergraduate states that because of that she can understand

\footnotetext{
4 This aspect is addressed in detail in the following subsection.
} 
why the educator teaches the way she does. As Andrade et al (2013) point out, heavy workloads prevent teachers from having time to plan their lessons. In the following excerpt, we focus on the lack of governmental incentives for teachers to keep studying.

\section{Excerpt 05}

Question: Is there a continuing education program for teachers and administrative staff?

Yes. The government offers some courses, although there are very few ones, and the teachers need to pay for most of them. $[\ldots][T]$ he teachers interested in continuing education need to seek ways to improve their teacher education on their own. (Practicum 1, Record 2, 13 May 2013)

For Andrade et al (2013) and Teixeira and Silva (2017), lack of interest and investments by the Brazilian government, concerning continuing teacher education programs and courses, are some of the elements that contribute to the precarious situation of English language teaching in public schools. Based on our experiences, we observe that most teachers that work in public school contexts are from low middle class and sometimes cannot afford extra education on their own. In addition, as shown in the previous excerpts, educators clearly lack time to participate in continuous teacher education programs and courses, precisely due to their enormous workloads.

The English classes

In some of the lessons student teachers attend, they are supposed to observe them and write down the methods and approaches used by the collaborating teachers, as well as other elements related to these topics. After that, in their essays they must write some reflections based on their notes. The following three excerpts are some examples of the undergraduate's descriptions and reflections:

\section{Excerpt 06}

After reflecting on the issues [...] [that] were based on LarsenFreeman (2000, p. 7-8), what information do they elicit about the topic "Methods and Approaches in Language Teaching"? What method(s) can be inferred from the practice of the teacher? 
V. 8 (3)

$320-335$

out-dez

2018

The method used to guide the [collaborating teacher B's] class is the Grammar Translation Method, because the main linguistic skill focused is reading. Students usually read something in the foreign language and then translate what they read into their mother tongue [Portuguese], or vice versa. Students memorize words, grammatical rules and verbal conjugations. Activities such as fill-in-the-blanks with words and grammatical structures studied are used, as well as reading comprehension questions. There is no effective communication in the foreign language, and translation is the focus. Everything is done in a very mechanical way, and the foreign language is seen as something completely abstract for the learners. (Practicum 3, Record 1, 05 and 12 May 2014, emphasis in original)

\section{Excerpt 07}

In summary, the elements that are effectively included in class are mainly the interpretation and translation of texts. The lessons basically revolve around grammar topics, vocabulary and text comprehension. The [collaborating] teacher [B] writes the grammatical topic on the board, students copy it and then the educator explains it. When the content to be given is related to vocabulary, the teacher uses the book or writes down lists of words on the board. When it comes to texts, the teacher reads them with students, asks them to answer some questions, always in Portuguese, and to do translations of them. (Practicum 4, Record 1, 27 August and 03, 10 and 17 September 2014)

\section{Excerpt 08}

The conclusion I have come to regarding the teacher's use of language skills in class is that she does her best by doing what she can in that context. I could notice that the collaborating teacher [B] has mastery of vocabulary and grammar of the language as well as has mastery of the reading, writing, speaking and listening skills. It must be pointed out that she always communicates with me in English, demonstrating her knowledge of the language. Nonetheless, due to all issues and problems already previously mentioned, it is extremely 
difficult to work with the four skills in an integrated way. As the class time is overly short, the teacher chooses to work with the reading and writing skills, focusing on translations and interpretation of texts. It is relevant to stress that these skills are exactly the ones PCN+ (BRASIL, 2002, p. 97) emphasize that must be addressed - "[t]he primary responsibility of teaching modern foreign languages in high school must be [teaching the] reading [skill] and, by implication, interpretation." Thus, the teacher tries, in a certain way, to follow what it is demanded by the documents, by the annual plan and by the textbooks that are sent to school. Her classes basically follow the Grammar-Translation Method. The teacher has been dealing with such crushing educational system for many years, and it was possible to note that she has been swallowed up by it, that is, she stopped trying to make different classes and to be a researcher teacher. Nowadays, she simply follows what it is required by the system. (Practicum 4, Essay 1, 20 October 2014)

As shown in the excerpts, aspects that are characteristic of the Grammar Translation Method permeate the classes described, such as the focus on reading and translation, memorization of words, fill-in-theblanks and reading comprehension activities, lack of communication in the target language, etc. Ifa's (2014) and Menezes's (2015) studies, which also focus on reports of student teachers, corroborate this investigation, as the authors underline that, in general, English language classes in public schools are still based on traditional teaching and concentrate on translation and grammar.

The classes described clearly do not appeal to learners, for as stated in excerpt 04, they are monotonous. The PCN affirm that

[...] the repetitive study of words and structures will only result in students' lack of interest in relation to the language, especially because without the opportunity to try interpreting and using it to communicate, they will see no reason to learn it. ${ }^{5}$ (BRASIL, 1998, p. 54).

\footnotetext{
5 Original quote: "[...] o estudo repetitivo de palavras e estruturas apenas resultará no desinteresse do aluno em relação à língua, principalmente porque, sem a oportunidade de arriscar-se a interpretá-la e a utilizá-la em suas funções de comunicação, acabará não vendo sentido em aprendê-la".
} 
V. 8 (3)

$320-335$

out-dez

2018

Marzari and Gehres (2015) point out that, because of the current conditions, English language classes are fully taught in Portuguese in most public school contexts, as it is reinforced by the undergraduate in excerpt 06. This is also characteristic of the Grammar Translation Method (LARSEN-FREEMAN, 2000; RICHARDS; RODGERS, 1986). Thereby, we perceive that English is studied without the intent of using it to communicate, and this is one of the aspects that possibly demotivates students. In this perspective, Marzari and Gehres (2015) highlight that listening and, mainly, speaking are neglected in classroom, as it is also observable in the excerpts aforementioned.

The PCN (BRASIL, 2000) underline that the practical objectives in teaching a foreign language are understanding, speaking, reading and writing, from which learners would be able to use the new language in real life situations. Nonetheless, the document itself states that, due to many issues and problems, teachers end up focusing on normative grammar, working primarily on the writing and reading skills. As a result, "[o]pportunities that students have to listen or speak a foreign language are rare" 6 (BRASIL, 2000, p. 28), and that demotivates them completely (BRASIL, 2006).

According to the PCN (BRASIL, 2000), the general principle concerning teaching a foreign language is to lead students to appropriately communicate in different situations of everyday life. However, learners finish high school not being even able to read simple texts in English, even though the reading and interpretation skills are the most focused aspects at schools. In addition, the PCN+ (BRASIL, 2002, p. 93) state that

[n]owadays there is no way to conceive an individual who, at the end of high school, continuing their academic education or not, is unable to make use of the foreign language in situations of contemporary life." 7

These statements are overly distant from the reality of the teaching and learning process at public schools. The OCEM ${ }^{8}$ (BRASIL, 2006) highlight that the skills that should be developed are the reading skill, oral communication and written practice, but clearly this is not what happens.

\footnotetext{
${ }^{6}$ Original quote: "[s]ão raras as oportunidades que o aluno tem para ouvir ou falar a língua estrangeira".

7 Original quote: "[n]ão há hoje como conceber um indivíduo que, ao término do ensino médio, prosseguindo ou não sua formação acadêmica, seja incapaz de fazer uso da língua estrangeira em situações da vida contemporânea".
}

${ }^{8}$ OCEM are Curriculum Guidelines for High School (Orientações Curriculares para o Ensino Médio), laid out by the Brazilian government, and used as pedagogical references and guidelines for teachers. 
In excerpt 08, the student teacher claims that the collaborating teacher B is fluent in English. Nevertheless, only knowing the language is not enough. The legal documents have many problems, as it is possible to perceive from the undergraduate's declarations and the previous discussion, as they lay out that teachers do things in certain way, although they are aware that the contexts do not provide the necessary conditions for educators to develop what is proposed. It seems that the student teacher does not blame the collaborating teacher for the problems observed, but rather tries to understand her actions, based on the experiences the educator lived over the years in the Brazilian public education system.

Impact of the practicum experience on the student teacher

In this subsection, we concentrate on perceptions of the undergraduate in relation to the impact her practicum experience had on her.

\section{Excerpt 09}

The observations made, the data collected, and the sharing sessions helped to strengthen my decision not to teach in public schools. Because I have already been teaching in a language school for over one year and a half, I cannot avoid comparing these two different realities. I do love teaching; however, I need to work in a place where I can feel well and that it be possible to see the reward for what I am doing, i.e. a place where I can feel fulfilled. La Guardia (2009) focuses on the importance of satisfaction or enjoyment while performing a job, pointing these aspects as intrinsically motivating activities. For example, for me it is amazing to see that my students are effectively learning a second language (in the language school where I work), which is possible indeed, because the staff there provides everything that is necessary for teachers to give good classes. Nevertheless, it would be frustrating to struggle so much for nothing, as it happens in public schools, due to so many factors that prevent teachers from developing a good learning environment. Therefore, the school infrastructure is doubtless a factor that affects teachers' work. A good environment is essential to create a good site to work and study. (Practicum 1, Essay 1, 15 May 2013) 
V. 8 (3)

$320-335$

out-dez

2018

\section{Excerpt 10}

Cook (2009) points out the importance of seeing teaching as a part of teachers' identities. Some of my classmates already see themselves as teachers, and indeed embody this identity. The feelings that the practicum has provoked on us are extremely diverse. Some student teachers still feel excitement, willing to help and make the difference, despite all problems we have seen. On the other hand, other student teachers - like me -, mainly the ones who have already taught for a while, say that they do not want to face that harsh reality. Some of them want to keep teaching, but not in public schools, due to the aspects already underscored. (Practicum 1, Essay 2, 29 May 2013)

As it is possible to observe from the undergraduate's claims, unfavorable workplace conditions may discourage student teachers from entering the profession, affirmation that is corroborated by Oliveira and Figueiredo (2013) and Borelli (2018), whose studies also focus on experiences of student teachers during their practicum. Making the decision not to teach, at least in public schools, due to the experiences they lived during their practicum, at that moment, was a choice that the undergraduate made, as well as some of her classmates, as she declares.

As many student teachers experience different realities, like teaching in language schools, even before finishing their undergraduate course, they end up comparing them to the reality of public schools. By comparing them, they might get disappointed because the conditions are usually different. These issues need to be addressed with undergraduates during their practicum, so they can better understand themselves and their teacher identities, their experiences, perceptions and emotions towards their (future) profession.

\section{Final remarks}

In the introduction, the following two questions that guided this study were presented:

a) Which aspects stand out in the practicum experience of an English student teacher?

b) How did the practicum experience affect the undergraduate? 
Regarding the first question, some of the issues that struck the student teacher the most were everyday problems and challenges faced by the collaborating teachers, such as overcrowded classrooms, learners' lack of interest, reduced time for English classes, incoherencies in the legal documents that guide pedagogical actions, among others. Besides that, heavy workloads imposed on educators as well as lack of governmental incentives were also elements highlighted by the undergraduate. The way classes were conducted was another aspect that demotivated her, regarding working as an English teacher in a context like the one where she did her practicum.

In relation to the second question, from what was shown, the practicum can be a life-changing experience for some student teachers, as they make professional choices based on the experiences they have. Therefore, it might affect them greatly, either to leave the profession or to remain in it, reaffirming the choice they had previously made.

\section{References}

ANDRADE, W. et al. O ensino da língua inglesa numa escola da Rede Pública Municipal: uma proposta de mudança nas circunstâncias em que se desenvolve o ensino desse idioma. Revista Lugares de Educação [RLE], Bananeiras/PB, v. 3, n. 7, p. 5-22, Edição Especial, dez. 2013.

BARCELOS, A. M. Narrativas, crenças e experiências de aprender inglês. Linguagem e Ensino, v. 9, n. 2, p. 145-175, 2006.

BERNARDO, A. C. Língua Inglesa na escola pública e a relação com o saber. Interdisciplinar, v. 4, n. 4, p. 94-105, dez. 2007.

BORELLI, J. D. V. P. O estágio e o desafio decolonial: (des)construindo sentidos sobre a formação de professores/as de inglês. 2018. 222f. Tese (Doutorado em Letras e Linguística) - Faculdade de Letras, Universidade Federal de Goiás, Goiânia, 2018.

BORG, S. Teacher cognition in language teaching: a review of research on what language teachers think, know, believe, and do. Language Teaching, v. 36, p. 81-109, 2003.

BRASIL. Secretaria da Educação Fundamental. Parâmetros Curriculares Nacionais: terceiro e quarto ciclos do ensino fundamental: língua estrangeira/ Secretaria da Educação Fundamental. Brasília: MEC/SEF, 1998.

BRASIL. Ministério da Educação. Secretaria de Educação Média e Tecnológica. Parâmetros Curriculares Nacionais (Ensino Médio). Brasília: MEC, 2000. p. $25-32$.

BRASIL. Ministério da Educação. Secretaria da Educação Média e Tecnológica. Parâmetros Curriculares Nacionais + $(\mathrm{PCN}+)$ - Linguagens, Códigos e suas Tecnologias. Brasília: MEC, 2002. p. 93-138. 
V. 8 (3)

$320-335$

out-dez

2018

BRASIL. Secretaria de Educação Básica. Ministério da Educação. Orientações Curriculares para o Ensino Médio (OCEM) - Linguagens, códigos e suas tecnologias. Brasília: Ministério da Educação/Secretaria de Educação Média e Tecnológica, 2006. p. 86-126.

COELHO, H. S. H. "É possível aprender inglês na escola?" Crenças de professores e alunos sobre o ensino de inglês em escolas públicas. 2005. $145 \mathrm{f}$. Dissertação (Mestrado) - Faculdade de Letras da UFMG, Belo Horizonte, 2005.

COOK, J. "Coming into my own as a teacher": identity, disequilibrium, and the first year of teaching. The New Educator, v. 5, n. 4, p. 274-292, 2009.

DENZIN, N. K.; LINCOLN, Y. S. Introduction: The discipline and practice of qualitative research. In:

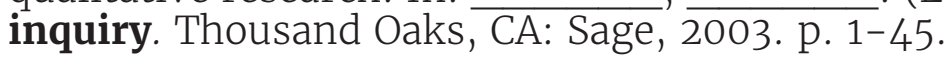
(Ed.). Strategies of qualitative

GODOY, A. S. Estudo de caso qualitativo. In: GODOI, C.; BANDEIRA-DE-MELLO, R.; BARBOSA DA SILVA; A. Pesquisa Qualitativa em Estudos Organizacionais: Paradigmas, Estratégias e Métodos. São Paulo: Saraiva, 2006. p. 115-146.

IFA, S. Estágio Supervisionado de Língua Inglesa: Experiências significativas para a construção de conhecimento sobre prática docente. Estudos Linguísticos e Literários, n. 50, p. 100-119, 2014.

\section{LARSEN-FREEMAN, D. Teaching Techniques in English as a Second} Language. Oxford: Oxford University Press, 2000.

LA GUARDIA, J. G. Developing who I am: a self-determination theory approach to the establishment of healthy identities. Educational Psychologist, V. 44, n. 2, p. 90-104, 2009.

LIMA, D. C.; SILVA, M. A. S. L. Impressões, implicações e reflexões contidas no relatório de estágio. In: FIGUEIREDO, F. J. Q.; SIMÕES, D. Contribuições da Linguística Aplicada para a Educaçã̃o Básica. Campinas, SP: Pontes Editores, 2018. p. 211-243.

MARZARI, G. Q.; GEHRES, W. B. S. Ensino de inglês na escola pública e suas possíveis dificuldades. Thaumazein, Santa Maria, v. 7, n. 14, p. 12-19, dez. 2015.

MENEZES, D. A. Ensino de inglês e formação de professores: reflexões sobre o contexto brasileiro. Educação \& Linguagem, v. 18, n. 2, p. 101119, jul.-dez. 2015.

MERRIAM, S. Case study research in education: A qualitative research. San Francisco: Jossey-Bass, 1988.

OLIVEIRA, H. F.; FIGUEIREDO, F. J. Q. O que o "não" nos diz: narrativas de licenciados em Letras que não se tornaram professores. In: OLIVEIRA, H. F.; SANTOS BICALHO, P. S.; MIRANDA, S. C. (Org.). Educação e diversidade: múltiplos olhares. Anápolis: Ed. da UEG, 2013. p. 117-138.

PONTES, V.; DAVEL, M. A. N. O inglês na escola regular: um desafio para o professor. Revista X, v. 1, p. 102-117, 2016. 
RICHARDS, J. C.; RODGERS, T. Approaches and Methods in Language Teaching. Cambridge: Cambridge University Press, 1986.

RICHARDS, J. C.; PENNINGTON, M. The first year of teaching. In: RICHARDS, J. C. (Ed.). Beyond Training. Cambridge: CPU, 1998. p. 173190.

TEIXEIRA, J. R. L; SILVA, V. R. Inglệs e a escola pública: um estudo do real. Revista do Programa de Pós-Graduação em Humanidades, Culturas e Artes - UNIGRANRIO, v. 1, n. 15, p. 1-13, 2017.

WEISS, E. Perceived workplace conditions and "first-year" teachers' morale, career choice commitment, and planned retention: a secondary analysis. Teaching and Teacher Education, v. 15, p. 861-879, 1999. 